\title{
Samsun Halk Sag̃lıg̃ı Laboratuvarında 2016-2018 Yılları Arasında İnfluenza ve Dig̃er Solunum Yolu Virüsleri Sürveyans Verilerinin Retrospektif Olarak Deg̃erlendirilmesi
}

\section{Retrospective Evaluation of Influenza and Other Respiratory Viruses Surveillance Data Between 2016-2018 in Samsun Public Health Laboratory}

\author{
Seda GÜDÜL HAVUZ'(IID), Funda ERDEM²(ID)
}

\footnotetext{
${ }^{1}$ Samsun Bafra Nafiz Kurt Devlet Hastanesi, Tıbbi Mikrobiyoloji Klinig̃i, Samsun, Türkiye

2 Samsun Halk Sag̃lıg̃ı Laboratuvarı, Mikrobiyoloji Bölümü, Samsun, Türkiye
}

Makale atıfı: Güdül Havuz S, Erdem F. Samsun halk sağlığı laboratuvarında 2016-2018 yılları arasında influenza ve diğer solunum yolu virüsleri sürveyans verilerinin retrospektif olarak değerlendirilmesi. FLORA 2021;26(1):172-82.

\section{ÖZ}

Giriş: Bu çalışmada Samsun Halk Sağlığı Laboratuvarında 2016 yılı, 2016-2017, 2017-2018 sezonlarındaki sentinel ve nonsentinel sürveyans verilerinin retrospektif olarak değerlendirilmesi amaçlanmıştır.

Materyal ve Metod: Samsun Halk Sağlığı Laboratuvarına sentinel olarak influenza benzeri hastalık (ILI) sürveyansı kapsamında, belirlenmiş aile hekimlerinden ve sentinel ağır akut solunum yolu infeksiyonları (SARI) sürveyansı kapsamında, belirli hastanelerden ve nonsentinel olarak burun ve nazofaringeal sürüntü örnekleri kabul edilmiştir. Bu örneklerde gerçek zamanlı polimeraz zincir reaksiyonu (qRt-PCR) yöntemi ile viral etkenler saptanmıştır.

Bulgular: ILI kapsamında 2.867 örnek, SARI kapsamında 3.189 örnek gerçek zamanlı polimeraz zincir reaksiyonu (qRt-PCR) yöntemi ile incelenmiştir. Çalışmamızda 2016 yılında; örneklerin 648'si pozitif olup, 542'si influenza A (3 tanesi influenza B ile birlikte olmak üzere 355 H1N1, 187 H3N2) ve 106'sı influenza B olarak tespit edilmiştir. 2016-2017 sezonunda örneklerin 180'i influenza virüsleri açısından pozitif olup 139'u influenza A H3N2, 41'i influenza B olarak saptanmıştır. 2017-2018 sezonunda örneklerin 290' influenza virüsleri açısından pozitif olup, 150'si influenza A (2 tanesi influenza B ile birlikte olmak üzere 135 H1N1, 15 H3N2) ve 140'ı influenza B olarak bulunmuştur. Diğer solunum yolu virüsleri açısından bakıldığında; üç yıllık sürede tüm yaş gruplarında, 417 örnekte influenza A H1N1 en sık saptanan virüs olmuştur. Ikinci sıklıkta ise, 323 örnekte respiratuvar sinsityal virüs (RSV) görülmüş olup, özellikle erken çocukluk yaş grubundaki pozitifliği dikkat çekicidir.

Sonuç: Genel olarak bölgeler düzeyinde yapılan ILI ve SARI sürveyans sonuçları ülke ve dünya verilerine paralellik gösterse de bazı farklılıklar ortaya çıkabilir. Bu çalışmada, dolaşımdaki virüs dağılımının, sezon pikinin az da olsa farklılılar gösterebileceği saptanmıştır. Griple mücadelede, gerekli önlemlerin alınmasında erkenden harekete geçmek için bölgesel sürveyans çalışmalarının önemli olduğunu düşünmekteyiz.

Anahtar Kelimeler: Influenza; Solunum yolu virüsleri; Sürveyans; Gerçek zamanlı PCR 


\title{
ABSTRACT \\ Retrospective Evaluation of Influenza and Other Respiratory Viruses Surveillance Data Between 2016-2018 in Samsun Public Health Laboratory
}

\author{
Seda GÜDÜL HAVUZ1' Funda ERDEM²
}

\footnotetext{
${ }^{1}$ Clinic of Medical Microbiology, Samsun Bafra Nafiz Kurt Public Hospital, Samsun, Turkey

2 Division of Microbiology, Samsun Public Health Laboratory, Samsun, Turkey
}

Introduction: The aim of this study was to retrospectively evaluate the sentinel and nonsentinel surveillance data of respiratory track viruses determined by the Samsun Public Health Laboratory during the 2016, 2016-2017 and 2017-2018 flu seasons.

Materials and Methods: Samsun Public Health Laboratory collected nasal and nasopharyngeal samples from the following sources: designated family medicine practitioners (within the scope of influenza-like illness [ILI] surveillance), selected hospitals (within the scope of severe acute respiratory illness [SARI] surveillance), and other sources that provided nonsentinel specimens. Viral agents were identified via real-time polymerase chain reaction ( $q R T-P C R)$.

Results: A total of 2867 ILI specimens and 3189 SARI specimens (from sentinel and nonsentinel sites) were collected and assessed. In 2016, 648 samples were tested positive, 542 were influenza A (187 H3N2 and 355 H1N1 - three were accompanied by influenza B), and 106 were influenza B. In 2016-2017, 180 samples were positive: 139 were influenza A (all H3N2) and 41 were influenza B. In 2017-2018, 290 samples were positive for influenza, 150 for influenza A (15 H3N2 and 135 H1N1 - two of which were accompanied by influenza B) and 140 for influenza B. Overall, influenza A H1N1 was identified as the most common respiratory virus in all ages during the 3 years of surveillance, with 417 positive results. The second most common virus, especially in the early childhood period, was the Respiratory syncytial virus (RSV) which was identified in 323 specimens.

Conclusion: In general, although the results of ILI and SARI surveillance performed at regional level are parallel to the country and world data, there may be differences. This study determined that circulating virus distribution and seasonal peak may differ slightly. We believe that regional surveillance studies are essential in taking early andnecessary measures to fight against influenza.

Key Words: Influenza; Respiratory tract viruses; Surveillance; Real-time polymerase chain reaction

\section{GíRiș}

Her y1 dünya nüfusunun \%5-20'sini etkileyen grip, influenza virüslerinin yol açtığı bir akut solunum yolu hastalığıdır. Riskli gruplarda önemli morbidite ve mortalite nedeni olan, toplumun büyük bir kısmını etkileyerek halk sağlığı problemlerine yol açan bir infeksiyon hastallğıldir ${ }^{[1]}$. Akut solunum yolu hastalikları toplumda en yaygin görülen infeksiyon hastaliklarındandır. Bu infeksiyonlar, özellikle cocuklarda yüksek oranda morbidite ve mortaliteye neden olurlar ${ }^{[2]}$. Akut solunum yolu infeksiyonlarının \%20-60'ndan virüslerin sorumlu olduğu düșünülmektedir. Cocuklarda en sik görülen etken genellikle respiratuvar sinsityal virüs (RSV) iken, erișkinlerde influenza virüsleridir ${ }^{[3]}$. Viral kaynaklı akut solunum yolu infeksiyonları cocuklarda ve yașl popülasyonda hastaneye yatma ve infeksiyon kliniklerine bașvurunun önemli nedenleri arasındadir ${ }^{[4,5]}$. En sik solunum yolları infeksiyonlarına neden olan virüsler; influenza virüs $\mathrm{A}$ (INF A) ve $\mathrm{B}$ (INF $\mathrm{B}$ ), insan parainfluenza virüs (HPIV) tip 1, 2, 3, 4, RSV A ve $B$, insan metapnömovirüs (HMPV), enterovirüs (EV), insan paraekovirüs $(\mathrm{HPeV})$, insan rinovirüs $(\mathrm{HRV})$, insan koronavirüs $(\mathrm{HCoV})$, insan bokavirüs $(\mathrm{HBoV})$ ve adenovirüsler (AV)'dir ${ }^{[6]}$.

Bölgelere göre influenza virüslerinin etkinliğinin bașladığ1 aylar, pik yaptığ1 dönemler ve bu dönemlerin süresi değișmektedir. Viral solunum yolu virüslerinin dağılımı, olgu tanımlarına, yașa, kullanılan moleküler yönteme ve incelenen örneğe göre değișkenlik gösterebilir.

Toplum kaynaklı pnömonilerin en sı nedeni influenza virüsleridir ${ }^{[7]}$. Ayrıca $\mathrm{HCoV}, \mathrm{AV}, \mathrm{RSV}$ ve HRV gibi diğer solunum virüsleri de influenza benzeri hastallk (ILI) ve toplum kaynakl pnömonilere neden olmaktadır. Viral solunum yolu infeksiyonlarında \%25-50 oranında uygunsuz antibiyotiklerin kullanımının olduğu tahmin edilmektedir ${ }^{[7]}$. Antibiyotik kullanımının en önemli nedeni kesin tanının konulamamasıdır. Antibiyotiklerin gereksiz kullanımı; maliyetin artmasına, toplumsal ve bi- 
reysel antibiyotik direncine ve antibiyotik ile ilișkili ishaller gibi cesitli yan etkilere neden olabilir ${ }^{[8]}$. Sürveyans stratejileri, viral solunum yolu hastalıklarını izlemek, etkilerini saptamak ve ampirik antibiyotik tedavisini belirlemek açısından önemlidir ${ }^{[7]}$ Duyarlllıkları düsüuk (\%27-70), özgülliükleri nispeten yüksek (\%95-100) olan hizlı antijen testleri ve sürveyans stratejileri ile uygunsuz antibiyotik kullanımının azaltılabileceği düșünülmektedir ${ }^{[7,9]}$.

Hastanede yatmayı gerektiren akut solunum yolu infeksiyonlarındaki viral etkenler içerisinde influenza en yaygın olanıdır ve așıla önlenebilmektedir $^{[7]}$. Hastalığın kontrol altına alınması önceden tasarlanmıș eylem planları ve güçlü bir sağlık sistemi ile mümkün olabilir. Grip sürveyansı yürütmek; sağlık otoritelerini uyarmak ve gerekli önlemlerin alınması açısından önem arz etmektedir.

Grip sürveyansı sayesinde; grip aktivitesinin bașlangıcı, bölgeler ve gruplar arasındaki farkl1lıklar, etkenin saptanması, değișimleri ve așı ile uyumu izlenebilmektedir. Ayrıca sürveyans; antiviral direnç durumunun, hedef grupların, olası epidemik ve pandemik sușların belirlenmesini sağlar ${ }^{[10]}$. Bu bilgiler ıșığında, gerekli önlemler alınarak ulusal hazırlık planlarının yapılabilmesi mümkün olmaktadır ${ }^{[10]}$.

Ülkemizde 2003-2004 grip sezonundan bașlamak üzere sentinel ILI sürveyans1, 2015-2016 grip sezonundan itibaren de sentinel ağır akut solunum yolu infeksiyonları (SARI) sürveyansı yürütülmektedir. Birinci basamak sağlık kurumları ile yürütülen sentinel sürveyansın yanı sıra, ulusal hastane bazlı sürveyansın bașlatılmıs olması, hem influenza aktivitesinin daha etkin bir biçimde izlenmesine hem de gerçek hastalık yükünün belirlenmesine katkı sağlayarak hastalık kontrol önlemlerinin ve ulusal așı politikalarının sekillenmesinde önemli rol oynamaktadır ${ }^{[11]}$. Samsun Halk Sağlığı Laboratuvarı, 2016 Ocak ayından itibaren ILI ve SARI sürveyansı calıșmalarına katılmaktadır.

Bu çalıșmada, 2016-2018 yılları arasındaki 3 yıllık dönemde ILI ve SARI sürveyans sonuçları retrospektif olarak analiz edilmiștir.

\section{MATERYAL ve METOD}

\section{Çalıșma Yöntemi}

Bu çalıșmada, Samsun Halk Sağlığı Laboratuvarında 2016 yılı, 2016-2017, 2017-2018 sezonlarındaki sentinel ve nonsentinel sürveyans verileri değerlendirilmiștir. Calıșma için yerel etik kuruldan etik onay alındı ve calıșmada Helsinki Bildirgesine bağlı kalındı. Samsun Halk Sağlığı Laboratuvarına sentinel olarak ILI sürveyansı kapsaminda belirlenmiș aile hekimlerinden ve SARI sürveyansı kapsamında belirli hastanelerden, ayr1ca belirlenen merkezler dıșında kalan sağlık kurum ve kuruluşlarından vaka tanımına uyan kișilerden nonsentinel olarak burun ve nazofaringeal sürüntü örnekleri gönderilmiștir. Sentinel ILI sürveyansı ve sentinel SARI sürveyansı kapsamındaki klinik örnekleri gönderen iller; Samsun, Sivas ve Trabzon'dur. Nonsentinel influenza sürveyansı kapsamındaki klinik örnekler Amasya, Corum, Giresun, Kastamonu, Ordu, Samsun, Sinop, Sivas, Tokat ve Trabzon illerinden gönderilmistir. Örnek gönderen iller Şekil 1'de gösterilmiștir.

\section{Örneklerin Seçimi}

Belirlenmiș 10 aile hekimi her hafta kendilerine bașvuran hastalar içerisinde ILI bulguları tașıan hastalardan en az birinden alınan nazal ve nazofaringeal örnekleri değerlendirilmek üzere laboratuvarımıza göndermișlerdir. Bu örneklerde influenza virüsleri çalıșılmıștır. Calıșmanın standardizasyonu açısından hekimlerden, Dünya Sağlık Örgütü (DSÖ) tarafından belirlenen ILI tanısı için ani bașlayan $38^{\circ} \mathrm{C}$ üzerinde ates, öksürük ve semptomların 10 gün içinde bașlamıs olması kriterlerine uymaları istenmiștir. SARI vaka tanımı yine DSÖ tarafından belirlenen, ILI için tanımlanan kriterlere ek olarak 10 gün içinde gelisen akut solunum yolu infeksiyonu ve hastaneye yatıs gerekliliğinin bir arada olması olarak kabul edilmiștir. Gönderilen örneklerde influenza ve diğer solunum yolu virüsleri calıș1mıștır. Vaka tanımına uyan ve belirlenen merkezler dıșında kalan sağlık kurum ve kurulușlarındaki kișilerden nonsentinel olarak gönderilen nazal ve nazofaringeal sürüntü örneklerinde de influenza ve diğer solunum yolu virüsleri calıșllmıștır.

Sürüntü örnekleri, hasta bilgi formu eșliğinde kurye sistemi ile viral transport besiyeri içerisinde soğuk zincir kurallarına uygun olarak laboratuvarımıza ulaștırılmıștır. Laboratuvarda numune kabul kriterlerine uyan örnekler calıșmaya alınmıștır. Virocult ${ }^{\circledR}$ Swab içindeki sürüntui örneği vortekslenerek kriyotupe aktarılmıstır. İki gün içerisinde calıșlacak örnekler $+4^{\circ} \mathrm{C}$ 'de, daha uzun süre bek- 


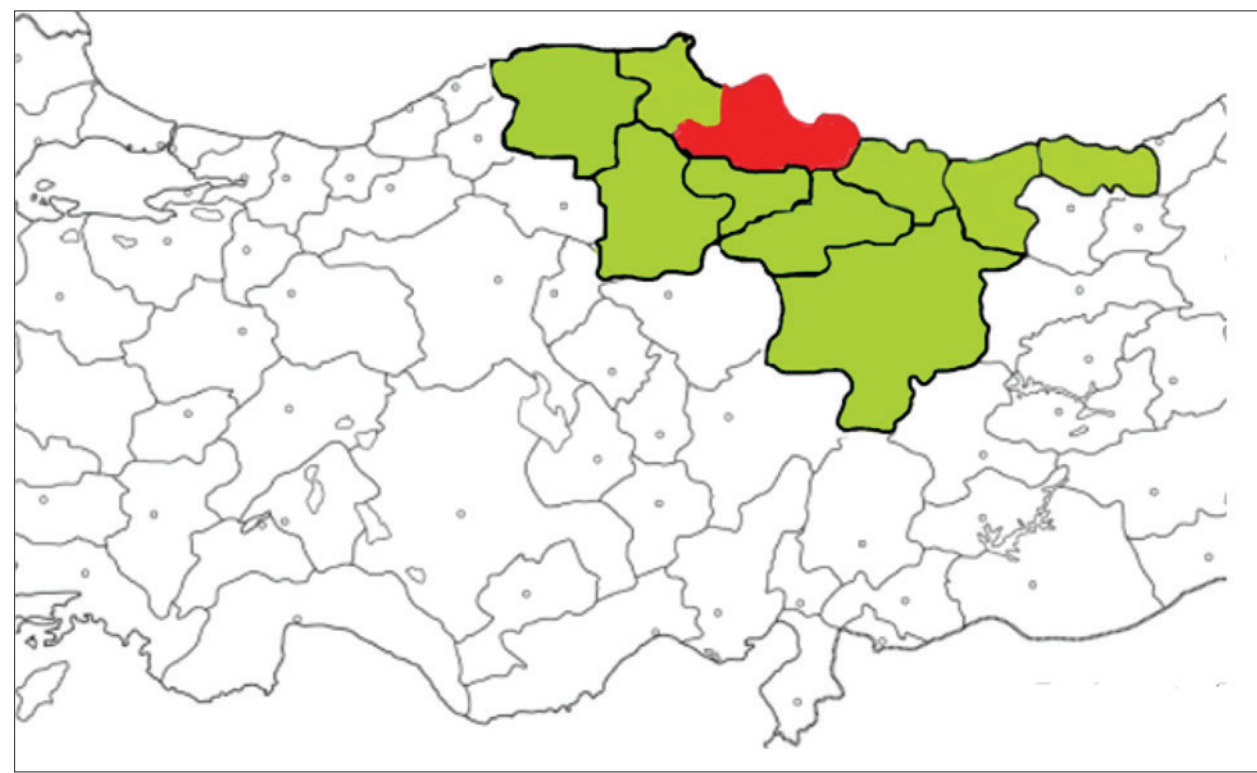

Şekil 1. Samsun Halk Sağlığı Laboratuvarına örnek gönderen iller.

letilecek örnekler $-20^{\circ} \mathrm{C}$ 'de saklanmıștır. Örneklerin hazırlanması ile ilgili tüm ișlemler biyogüvenlik kabininde gerçekleștirilmiștir. Nazal ve nazofaringeal sürüntü örneğinden viral RNA ekstraksiyonu, EZ1 Virus Mini Kit V 2.0 (QIAGEN, Almanya) ile EZ1 Advanced XL (QIAGEN, Almanya) cihazında yapilmıștır. Gerçek zamanlı polimeraz zincir reaksiyonu (qRt-PCR) RotorGene 6000 (QIAGEN, Almanya) cihazında üretici firmanın direktifleri doğrultusunda yapılmıștır. ILI olgularına ait örneklerde; INF A, H1N1 ve INF B'nin tespiti için FTD ${ }^{\circledR}$ FLU kiti (Fast Track Diagnostics, Malta) ve INF A alt tipleri olan H1N1, H3NX, H5NX, H7NX'in tespiti için de FTD ${ }^{\circledR}$ FLU Differantiation kiti (Fast Track Diagnostics, Malta) üretici firmanın önerileri doğrultusunda kullanılmıștır. SARI olgularına ait örnekler için FTD ${ }^{\circledR}$ Respiratory Pathogens 21 (Fast Tract Diagnostics, Lüksemburg) kiti kullanılmıștır. Bu kit, influenza ile birlikte 21 solunum yolu virüsünü; INF A H1N1, INF B, HRV, HCoV (NL63, 229E, OC43, HKU1), HPIV (tip 1, 2, 3, 4), HMPV (A/B), $\mathrm{HBoV}, \mathrm{RSV}(\mathrm{A} / \mathrm{B}), \mathrm{AV}, \mathrm{EV}, \mathrm{HPeV}$ ve Mycoplasma pneumoniae'yi saptamaktadır.

\section{BULGULAR}

Bu calıșmada, 1 Ocak 2016-31 Aralık 2018 tarihleri arasında Samsun Halk Sağlığı Laboratuvar1 verileri retrospektif olarak incelenmiștir. ILI kapsamında 2.867 örnek, SARI kapsamında 3.189 örnek çalıșmaya dahil edilmiștir. ILI kapsamındaki örneklerin 976's1 (\%34) çocuk, 1.891'i (\%66) eriskin yas gubuna aittir. SARI kapsamindaki örneklerin 1.131 'i (\%35.5) cocuk, 1.885'i (\%59.1) eriskin olup 173 (\%5.4) örneğin yas bilgisi saptanamamıștır.

\section{Yılı Sürveyans Bulguları}

2016 yllinda, sentinel ve nonsentinel ILI kapsaminda, ocak ayından bir sonraki dönemin bașlangiC1 olan ekim ayına kadar laboratuvarımıza toplam 1.246 örnek gelmiștir. Örneklerin 5 tanesi uygunsuz olup reddedilmiștir. Örneklerin 648'i (\%52.2) influenza virüsleri açısından pozitif iken 593 örnek (\%47.8) negatif olarak bulunmustur. Pozitif örneklerin 542'si (\%83.6) INF A olup, 355'i (\%65.5) INF A H1N1 (3 tanesi INF B ile birlikte), 187'si (\%34.5) INF A H3N2 olarak saptanmıstır (5 tanesi INF B ile birlikte pozitif). INF A saptanan toplam 8 örnekte INF B pozitifliğinin eșlik ettiği görülmüsstür. Pozitif örneklerin 106'sinda (\%16.4) sadece INF B saptanmıștır. Yas gruplarına göre dağılımlar Sekil 2'de gösterilmiștir. 2016 yll grip sezonunda, özellikle INF A'nın eriskin yas grubunda daha fazla saptandığı, INF B'nin ise 5-17 yas grubunda en sık saptandığ1 gözlenmiștir. Bu sezonda, INF A H1N1 baskın tip olup 2016 yilının 2-5. haftalarında yoğun görülmekle birlikte 2. haftada pik yapmıstır. 10-17 haftalar arasında ise INF B baskın olmuștur. 2016 yilı influenza alt tiplerinin haftalara göre dağılımı Sekil 3'te verilmiștir. 


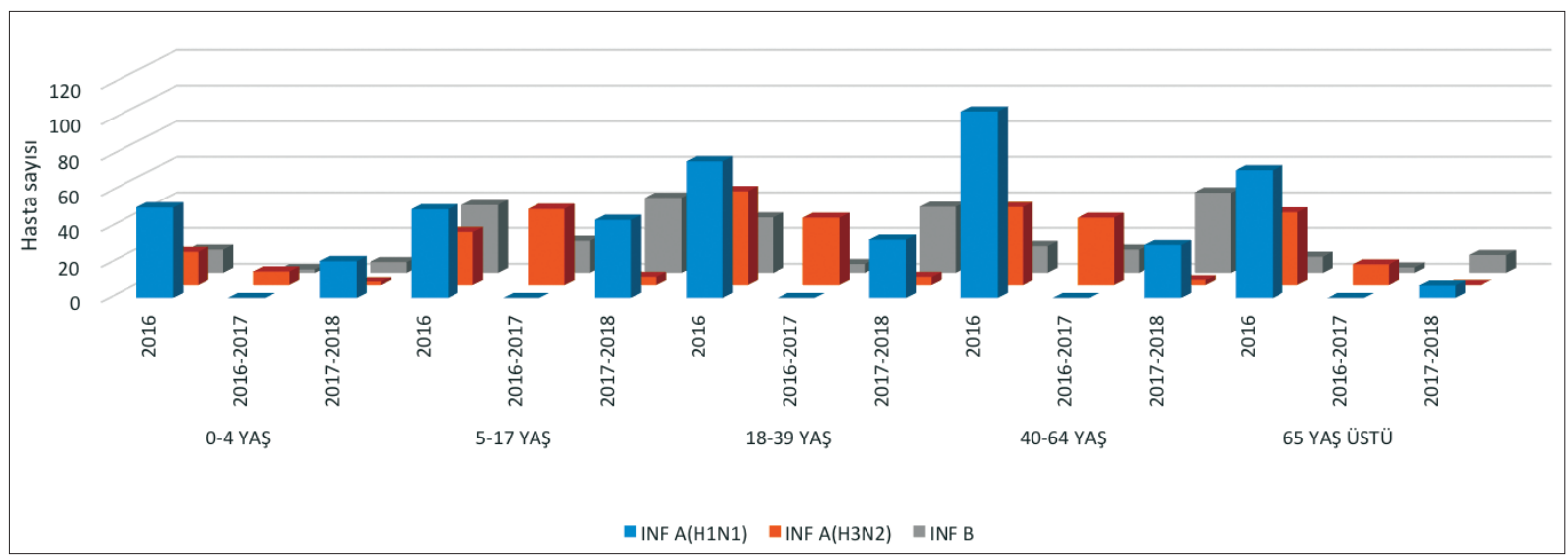

Şekil 2. 2016-2018 yıllarında influenza alt tiplerinin yaş gruplarına göre dağıımı.

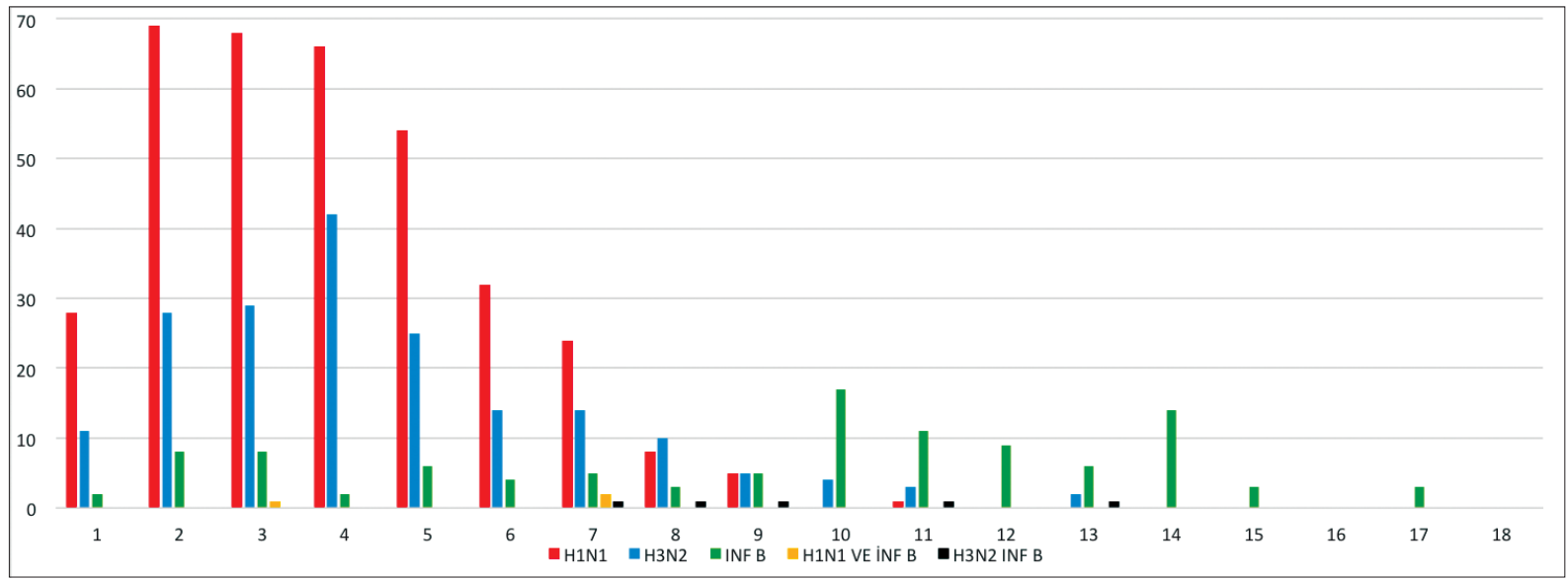

Şekil 3. 2016 yılı influenza alt tiplerinin haftalara göre dağılımı.

2016-2017 İnfluenza Sezonu Sürveyans Bulguları

2016-2017 sezonunda, sentinel ve nonsentinel ILI sürveyansı kapsaminda laboratuvarımıza toplam 655 örnek gelmiștir. Örneklerin 180 'i (\%27.5) influenza virüsleri açısından pozitif iken 475 örnek negatif olarak bulunmustur. Pozitif örneklerin 139'u (\%77.2) INF A H3N2, 41'i (\%22.8) INF B olarak saptanmıștır. 2016-2017 grip sezonunda INF A H3N2 dolașımda olup, bir önceki sezondan farklı olarak hiçbir örnekte INF A H1N1'e rastlanmamıstır. INF A H3N2 3. haftada pik yapmakla birlikte 1-11. haftalar arasında sık görülmüstür. 11-23. haftalar arasında yerini INF B'ye birakmıs, 49. haftada tekrar ortaya cikmıstır. 2016-2017 sezonu influenza alt tiplerinin haftalara göre dağılımı Sekil 4'te verilmiștir. Bu sezonda, INF A H3N2 özellikle 5-64 yas grubun- da saptanmıștır. Yaș gruplarına göre dağılımlar Sekil 2'de gösterilmiștir.

\section{7-2018 İnfluenza Sezonu Suirveyans Bulguları}

2017-2018 sezonunda, sentinel ve nonsentinel ILI sürveyansı kapsamında laboratuvarımıza toplam 977 örnek gelmiștir. Örneklerin 290'1 (\%29.7) influenza virüsleri açısından pozitif iken 687 örnek negatif olarak bulunmustur. Pozitif örneklerin 150'si (\%51.7) INF A olup, 140'1 (\%48.3) INF B olarak saptanmıștır. INF A pozitif örneklerin, 135'i (\%90) INF A H1N1 (2 tanesi INF B ile birlikte), 15'i (\%10) INF A H3N2 olarak saptanmıștır. Yas gruplarına göre dağılımlar Sekil 2'de gösterilmiștir. 2017-2018 grip sezonunda, INF B'nin 4 ve 14. haftalarda sık görüldüğü ve 10. haftada pik yaptığı (Sekil 5), özellikle 5-64 yas grubunu etkilediği saptanmıștır (Sekil 2). INF 


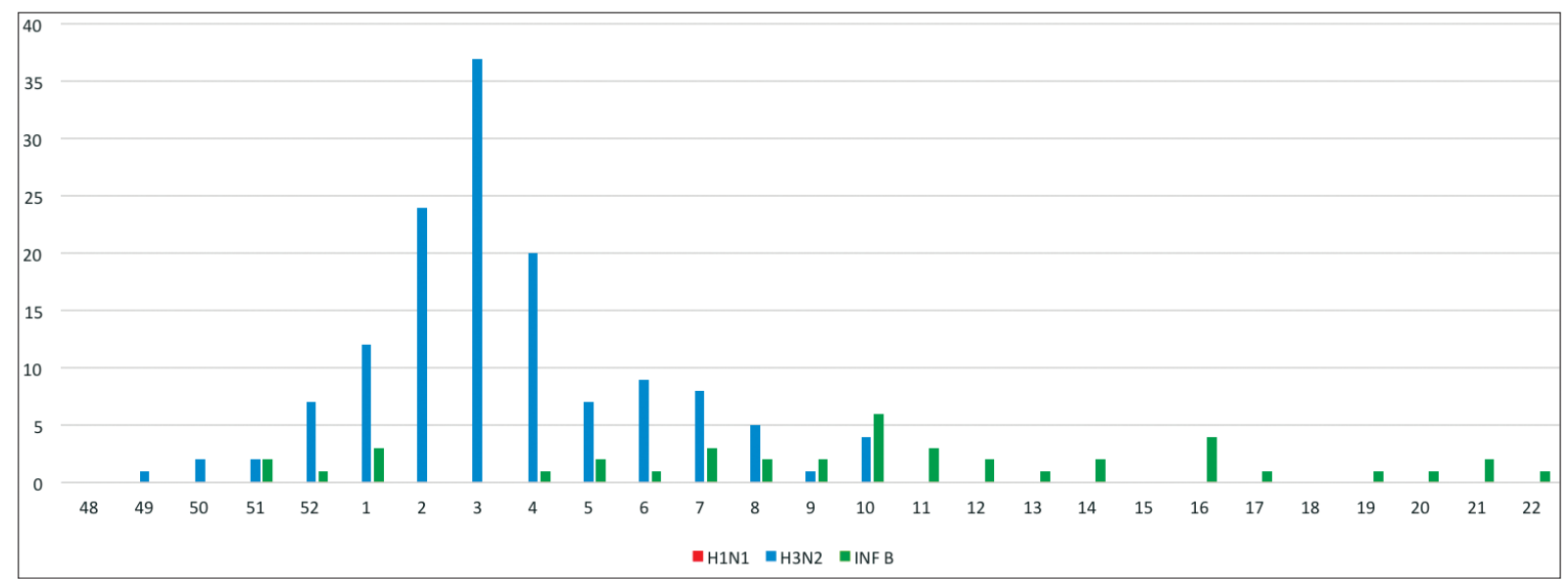

Şekil 4. 2016-2017 sezonu influenza alt tiplerinin haftalara göre dağılımı.

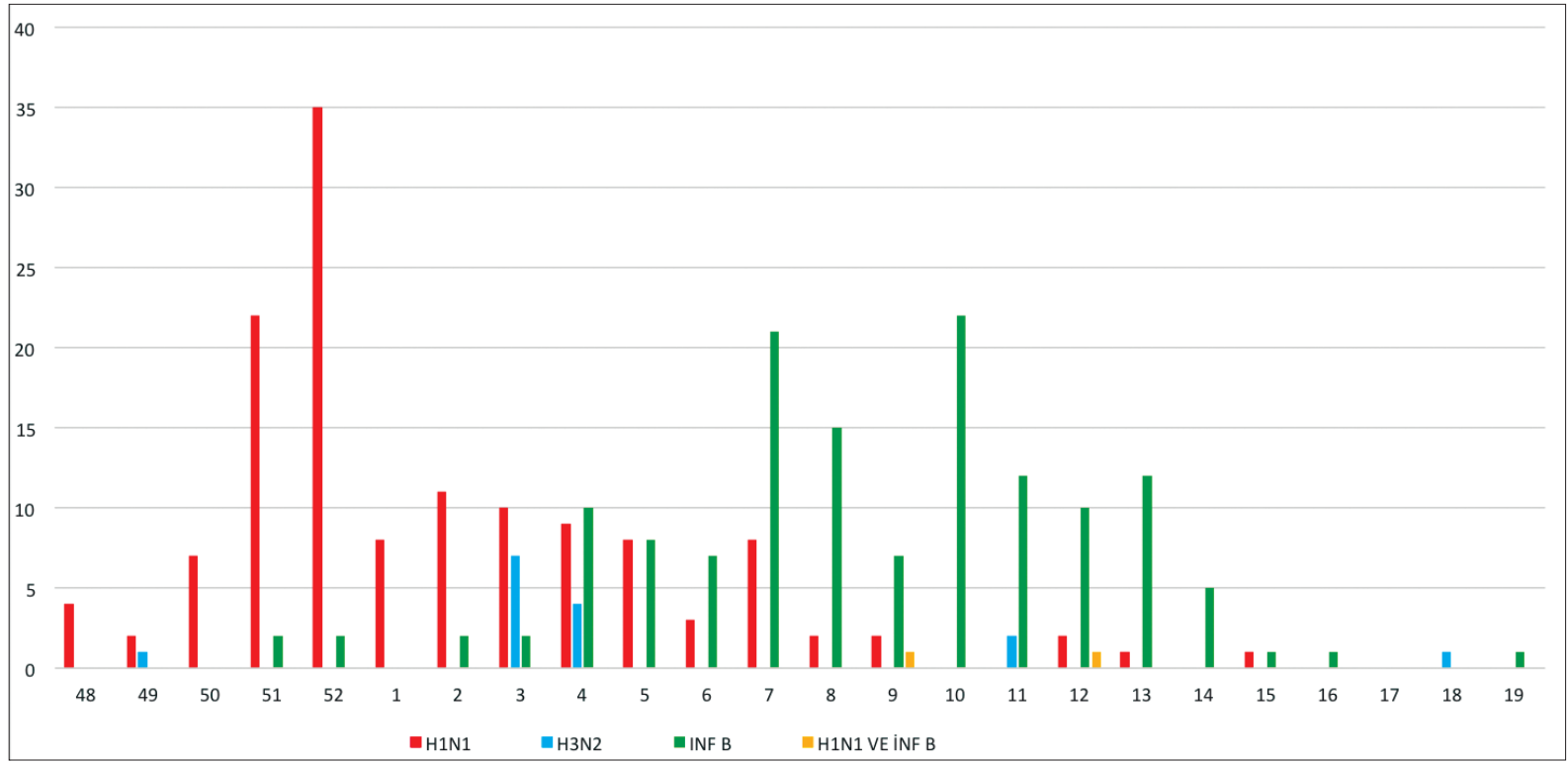

Şekil 5. 2017-2018 sezonu influenza alt tiplerinin haftalara göre dağılımı.

A H1N1 ise 50/2017 haftadan itibaren 7/2018 haftaya kadar yoğun olarak ve 5-64 yas grubunda baskın olmustur. 52/2017 haftada pik yapan INF A H1N1 16/2018 haftadan sonra görülmemistir. 2017-2018 sezonu influenza alt tiplerinin haftalara göre dağılımı Șekil 5'te gösterilmiștir.

SARI kapsamında üc yılda toplam 3.189 örneğin, 1.804 'ü pozitif, 1.385 'i negatif olarak saptanmıstır. Cocuk (0-17) yas grubunda örneklerin 819'unda, eriskin yas grubunda 883'ünde ve doğum tarihi bilgisi olmayan örneklerin 102'sinde virüs pozitifliği bulunmustur. Üc yılllk sürede, tüm yas gruplarında, 417 örnekte INF A H1N1 en sık saptanan virüs olmustur. İkinci sıklıkta ise,
323 örnekte RSV görülmüs olup, özellikle erken cocukluk yas grubundaki pozitifliği dikkat cekicidir. 0-4 yaș grubunda en sık saptanan virus RSV olup, 2016 yill, 2016-2017 ve 2017-2018 sezonlarında sırasıyla \%32, \%41.5 ve \%37.8 olarak saptanmıștır. Üc yılllk dönemde virüslerin yașlara göre dağılımı Șekil 6'da gösterilmiștir. 2016-2018 yılları arasında toplam 116 örnekte ikili virüs pozitifliği saptanmıștır. İkili virüs pozitifliği Tablo 1 'de gösterilmistir. 2016 yllında 33 örnekte ikili virüs, 4 örnekte ise üçlü virüs pozitifliği saptanmiștır. 2016-2017 ve 2017-2018 sezonlarında, sırasıyla ikili virüs pozitifliği, 36 ve 47 iken üçlü virüs pozitifliği ise sırasıyla 7 ve 5 olarak sap- 


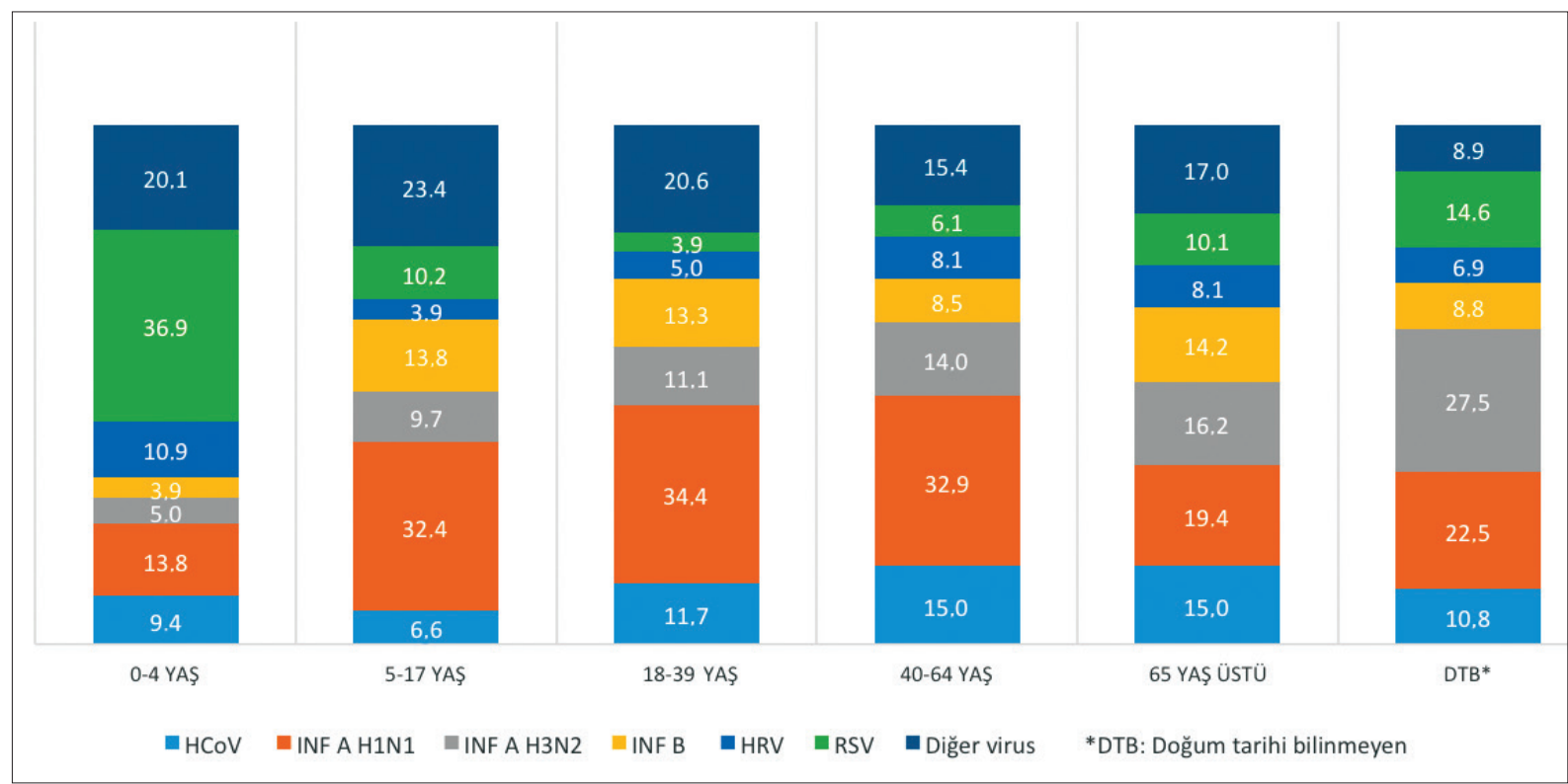

Şekil 6. Üç yıllık dönemde SARI kapsamında virüslerin yaşlara göre dağııımı.

Tablo 1. Üç yıllık dönemde SARI kapsamında ikili virüs pozitifliği

\begin{tabular}{lccccccccccc} 
& HCoV & RSV & H1N1 & H3N2 & HMPV & HPIV & HRV & iNF B & EV & HBoV & AV \\
\hline HCoV & & 15 & 8 & 4 & 3 & 8 & 2 & 1 & 0 & 2 & 2 \\
RSV & 15 & & 3 & 2 & 2 & 0 & 10 & 1 & 0 & 1 & 3 \\
H1N1 & 8 & 3 & & 1 & 1 & 1 & 0 & 2 & 0 & 1 & 3 \\
H3N2 & 4 & 2 & 1 & & 2 & 0 & 2 & 1 & 0 & 1 & 1 \\
HMPV & 3 & 2 & 1 & 2 & & 0 & 4 & 1 & 0 & 1 & 2 \\
HPIV & 8 & 0 & 1 & 0 & 0 & & 1 & 0 & 0 & 1 & 4 \\
HRV & 2 & 10 & 0 & 2 & 4 & 1 & & 0 & 4 & 1 & 4 \\
INF B & 1 & 1 & 2 & 1 & 1 & 0 & 0 & & 0 & 0 & 0 \\
EV & 0 & 0 & 0 & 0 & 0 & 0 & 4 & 0 & & 0 & 0 \\
HBoV & 2 & 1 & 1 & 1 & 1 & 1 & 1 & 0 & 0 & 2 \\
AV & 2 & 3 & 3 & 1 & 2 & 4 & 4 & 0 & 0 & 2
\end{tabular}

HCoV: Insan koronavirüsü, RSV: Respiratuvar sinsityal virüsü, H1N1: İnfluenza A (H1N1), H3N2: influenza A (H3N2), HMPV: İnsan metapnömovirüsü, HPIV: İnsan parainfluenza virüsü, HRV: İnsan rinovirüsü, INF B: İnfluenza B virüsü, EV: Entero virüs, HBoV: İnsan bokavirüsü, AV: Adenovirüs.

tanmıștır. Ocak, Subat ve Mart ayları, üç yıllık dönemde örnek sayısı ve virüs pozitifliğinin en fazla olduğu aylar olmuștur.

\section{TARTIȘMA}

Grip, ciddi morbidite ve mortaliteye yol açmasının yanında önemli ekonomik kayılara neden olmaktadır. Centre for Disease Control and Prevention (CDC), 1 Ekim 2019 ve 4 Nisan 2020 tarihleri arasında Amerika Birleșik Devletleri'nde
39-56 milyon kișinin gribe yakalanacağını, 410760 bin kișinin hastaneye yatacağını ve 24-62 bin kișinin hayatını kaybedeceğini öngörmüștürr ${ }^{[12]}$. İnfluenza virüslerinin antijenik yapılarında sürekli değișim olup bu değișimler epidemi ve pandemilere neden olabilmektedir.

$\mathrm{Bu}$ hastalıkla mücadelede, așı ile birlikte sürveyans çalıșmaları önemlidir. İnfluenza sezonunda sorumlu olan alt tiplerin belirlenmesi, pik dönemi, 
grip sezonunun bașlangıc ve bitis tarihleri dikkate alınmalidır ${ }^{[13]}$

İnfluenzayı önlemek ve ondan korunmak için 1. basamak aile hekimliği ve hastaneler seviyesinde sürveyans yürütmek önemlidir. Ulusal sürveyans çalısmaları ile elde edilen veriler, DSÖ, Global İnfluenza Sürveyans ve Yanit Sistemi "Global İnfluenza Surveillance and Response System" (GISRS) ile paylașllmakta ve dünyadaki grip aktivitesi izlenmektedir.

Avrupa Hastalıkları Önleme ve Kontrol Merkezi "European Centre for Disease Prevention and Control" (ECDC) 2015-2016 sezon verilerine göre Avrupa'da grip, düsüik aktivitede olmak üzere toplam 22 hafta sürmüstür. INF A H1N1 pdm09 ve Victoria lineage type $\mathrm{B}$ baskınlığında geçmiștir. Sezon piki, 11/2016 haftada olup en sik INF A H1N1 görüldüğü bildirilmiștir. İnfluenzaya bağl yoğun bakım ünitelerine yatan hastaların büyük coğunluğundan INF A H1N1 virüsü sorumlu olup, hastaların \%60'ı 15-64 yas grubunu içermiștir [14].

Halk Sağlığı Genel Müdürlüğu (HSGM) verilerine göre, bu sezonda her üc mevsimsel influenza tipi izole edilmekle birlikte INF A H1N1'in baskın tip olduğu vurgulanmıștır ${ }^{[15]}$. Bizim calıșmamızda da, INF A H1N1 en sık saptanan virüs olmuștur. ECDC verilerine paralel olarak calıșmamızda da INF A H1N1, erișkin yaș grubunu daha fazla etkilemiștir. HSGM'nin verileri ile paralel olarak calıșmamızda da pozitiflik en cok 2/2016 haftada olmustur. 2015-2016 sezonunda ülkemizde influenza aktivitesi aralık ayında bașlamıs, ocak ayında en yüksek seviyeye ulașmıștır, bir önceki sezonla kıyaslandığında cok daha erken bașlamıștır[15]. ECDC'nin verilerine göre Avrupa'daki sezon pikinin 11/2016 hafta olması nedeni ile ayrıșmıștır. $\mathrm{Bu}$ sezon ülkemizde her iki INF A alt tipinde es zamanlı homojen kosirkülasyonu görülmüs olup INF B daha geç dönemde sirkülasyona katılmıștır.

2016-2017 döneminde Avrupa'da influenza vakaları 46. haftada görülmekle, son beș yılın en erken sezon bașlangic1 olmuștur. Sezon orta yoğunlukta geçmiș olup, 27 hafta kadar sürmüștür. Avrupa'da pozitiflik oranı 52/2016 ile 5/2017 haftaları arasında pik noktaya ulașmıștır. Sezon boyunca tüm sentinel örneklerin \%76'sından sorumlu olan baskın virüs INF A H3N2 olmuș- tur. Bu alt tip, özellikle yașlı popülasyonu etkilemekle birlikte 65 yaș üzerindeki yoğun bakım hastalarının 2/3'sinde cok daha ciddi seyretmiștir $^{[16]}$. HSGM verilerine göre sentinel örneklerde, 2016'nın 43. haftası itibarı ile bir numunede INF A H3N2 tespit edilmesi ile sezon bașlamıs ancak 47. haftaya kadar INF A H3N2 pozitif örnek tespit edilmemiștir. Pik seviyeye 2017'nin 1. haftasında ulașılmıs, 7. haftadan itibaren INF B daha fazla görülmüștür. 2016-2017 sezonunda sentinel ILI sürveyans kapsamında pozitif örneklerin, \%67.9'unda INF A H3N2 bulunmuștur ${ }^{[17]}$. Bizim çalıșmamızda ILI sürveyansı kapsamında sentinel ve nonsentinel pozitif örneklerin \%77.2'si INF A H3N2 olarak saptanmıs olup bir önceki sezondan farklı olarak hiçbir örnekte INF A H1N1'e rastlanmamıstır. Pik seviyeye ECDC ve HSGM verilerine göre daha gec 3. haftada ulașılmıștır. ECDC'nin verilerinden farklı olarak örneklerin hiçbirinde INF A H1N1 görülmemiștir. Bizim çalısmamızda INF A H3N2 özellikle 5-64 yaș grubunda daha sık saptanmıs olup bir önceki sezonla benzerlik göstermektedir. Kres, okul, is hayatı ve sosyal hayat içinde daha cok olan yas grubunun etkilendiği düșünülmektedir.

2017-2018 döneminde Avrupa'da influenza aktivitesi 47/2017 haftada bașlayıp 18/2018'de sonlamıștır. Avrupa'da sentinel örneklerin \%64'ü INF B olarak saptanmıștır. Pik, Güney Avrupa'da ocak ayının bașında iken kuzey Avrupa'da subat ayının ortalarında yașanmıștır. Baskın olan virüs INF B olup geçmiș sezonlarla karșlaștırıldığında dolașımı daha yüksek seviyelerdedir. Șiddetli vakaların çoğu INF B infeksiyonundan kaynaklanmakta olup 40 yaș ve üzeri kișilerdir. Sentinel kaynaklarda saptanan INF A H1N1 pdm09 virüsleri, INF A H3N2 virüslerinden daha yüksek oranda bulunmuștur. Buna karșın nonsentinel olarak tespit edilen INF A H3N2 virüsleri ile INF A H1N1 pdm09 virüslerinin oranları benzer bulunmuștur ${ }^{[18]}$. HSGM verilerine göre, sentinel pozitif örneklerin \%54.2'si INF B olup önceki sezonlarla kıyaslandığında dolașımdaki INF B virüsleri daha yüksek düzeydedir ${ }^{[19]}$. Calıșmamızda bu sezonda pozitif örneklerin \%51.7'si INF A olup, \%48.3'ü INF B olarak saptanmıștır. INF A pozitif örneklerin, \%90'1 INF A H1N1 olarak saptanmıstır. Bizim bölgemizde INF B'nin piki, ECDC verilerinden 
farklı olarak daha gec görülmüs, benzer olarak aynı yaș grubu etkilenmiștir. HSGM verilerine göre ülkemizde, Avrupa'dan farklı olarak INF B daha az oranda saptanmıștır. Bizim calıșmamız Avrupa'ya göre iki noktada farklılık göstermektedir. Birincisi, INF A oranı INF B oranından daha yüksek saptanmıștır. İkincisi ise INF B pikinin, ECDC verilerine göre Kuzey Avrupa'da subat ay1nın ortalarında, bizim bölgemizde ise mart ayının bașında biraz daha gec görülmüs olmasıdır.

Çiblak ve arkadașlarının yaptığı bir calıșmada grip aktivitesinin ve izolasyonlarin ileri tarihlere kaydığı virüs izolasyonları için pikin ocak-şubat aylarında gerçekleștiği ve influenza virüslerinin nisan ayı sonlarına kadar dolașımda oldukları saptanmıș ve grip așısının önceki yıllardan farklı olarak ilkbahar aylarına kadar uygulanabileceği vurgulanmıștır $^{[1,20]}$. Bizim calıșmamızda da influenza virüsleri ilkbahar aylarına kadar dolașımda kalmıșlardır.

SARI sürveyansı kapsamında laboratuvarımıza gelen örneklerde üc yıllık sürede, tüm yas gruplarında, INF A H1N1 en sik saptanan virüs iken, ikinci sıklıkta ise RSV görülmüștür. Altas ve arkadașlarının yaptığı, ardıșık beș sezonun değerlendirildiği çalıșmada diğer solunum yolu virüsleri arasında en sık HRV görülmüștür ${ }^{[21] . ~ 2011-2014 ~}$ yılları arasında Kuzey Vietnam'da yapılan SARI çalısmasında \%32.1 oranında influenza virüsleri saptanırken, diğer solunum yolları virüslerinden en sık HRV'ye rastlanılmıș ${ }^{[22]}$ olup bizim calıșmamızdan farklı olarak bulunmustur. Ủc yıllık dönemde, örnek sayısı ve virüs pozitifliği açısından pik noktaya ocak aylarında ulașılmıștır. Yılın diğer aylarında düșük yoğunluklu olarak saptanmıștır. Bașaranoğlu ve arkadașlarının yaptığı bir calıșmada da RSV aktivitesinin en yüksek Subat ayında olduğu belirlenmiștir ${ }^{[23]}$. Calıșmamızda 2016-2018 yılları arasında, ikili koinfeksiyon oranı \%6.4 ve üclü koinfeksiyon oranı \%0.9 olarak saptanmıștır. Horton ve arkadașları tarafından 2007-2014 yılları arasında yapılan SARI sürveyans çalıșmasında, viral koinfeksiyon oranı \%5.4 iken, tüm örneklerin \%5.1'inde ikili virüs, \%0.2'sinde üclü virüs, $\% 0.1$ 'inde dörtlü virüs pozitifliği saptanmıstır ${ }^{[24]}$. Altaș ve arkadașları ardıșı bes sezonu inceledikleri çalıșmalarında koinfeksiyon oranını \%2-7 olarak bulmușlardır [21].
Sürveyans sayesinde, virüslerin coğrafik dağılım sekli, dolașımda bulunan tüm virüs tiplerinin saptanması ve morbidite verileri toplanarak ülkenin grip aktivitesi belirlenmektedir. Așının etkinliği dolașımdaki virus tiplerinin belirlenmesi ile değerlendirilebilir $^{[25]}$. Laboratuvarımız, 2016 ocak ayından itibaren ILI ve SARI sürveyansına katılarak hem bölge verileri, hem de ülke verilerine katkı sağlamaktadır. Bu calıșma, bölgemizdeki viral solunum yolu infeksiyonlarının oranını ve etkenlerin dağıl1minı ortaya koyması açısından klinisyenlere ipuçları vermektedir. Solunum yolu infeksiyonlarının qRt-PCR ile viral kaynaklı olduğunu saptamak, gereksiz antibiyotik kullanımını azaltacak ve antibiyotiklere direnç gelișiminin önlenmesine katkıda bulunacaktir.

Sonuc olarak, bulgularımız grip sezonunun pik yaptığı zaman ve epidemiyolojik özellikler açısından Avrupa'daki ülkelerden farkl1lik göstermektedir. Sürveyans programlarına katılarak bölgelerin ve ülkelerin kendi verilerini elde etmesi alınacak önlemler açısından önem tașımaktadır. Koronavirüs pandemisini yașadığımız bugünlerde solunum yolu infeksiyonlarına neden olan viral etiyolojik ajanların sürveyansını yürütmenin önemi bir kez daha ortaya çkmıștır. Dünyanın herhangi bir noktasında ortaya cıkan bulașıcı bir hastalık kısa sürede tüm dünyayı etkisi altına alıp hayatı durdurma noktasına getirebilmektedir. Erken uyarı sitemleri ve sürveyans sayesinde farkındalığı arttırmak ve gerekli önlemleri almak bundan sonraki dönemlerde de cok önemli olacaktır.

\section{TEŞEKKÜR}

$\mathrm{Bu}$ makalenin yazımındaki desteklerinden dolayı Prof. Dr. Ayșegül Taylan Özkan'a tessekkür ederiz.

\section{ETIK KURUL ONAYI}

Calıșma için Sağlık Bilimleri Üniversitesi Samsun Eğitim ve Araștırma Hastanesi Girișimsel Olmayan Klinik Araștırmalar Etik Kurulundan onay alındı (Karar no: GOKA/2020/12/9 Tarih: 12.09.2020).

\section{ÇIKAR ÇATIŞMASI}

Yazarlar bu makale ile ilgili herhangi bir çkar catıșması bildirmemișlerdir. 


\section{YAZAR KATKISI}

Anafikir/Planlama: SGH

Analiz/Yorum: SGH

Veri Sağlama: SGH, FE

Yazım: SGH

Gözden Geçirme ve Düzeltme: SGH, FE

Onaylama: SGH

\section{KAYNAKLAR}

1. Ciblak MA, Tütenyurd MK, Asar S, Tulunoğlu M, Fındıkçı $N$, Badur S. 2003-2012 yıllarını kapsayan dokuz sezonda grip sürveyansı bulguları: Istanbul Tıp Fakültesi Ulusal influenza Referans Laboratuvarı Sonuçları. Mikrobiyol Bul 2012;46(4):575-93.

2. Williams BG, Gouws E, Boschi-Pinto C, Bryce J, Dye C. Estimates of world-wide distribution of child deaths from acute respiratory infections. Lancet Infect Dis 2002;2(1):25-32.

3. Ciçek C, Bayram N, Anıl M, Gülen F, Pullukçu H, Saz EU ve ark. Solunum virusları ve influenza $A$ virus alt tiplerinin multipleks PCR yöntemi ile aynı anda saptanması. Mikrobiyol Bul 2014;48(4):652-60.

4. Liu J, Ai H, Xiong Y, Li F, Wen Z, Liu W, et al. Prevalence and correlation of infectious agents in hospitalized children with acute respiratory tract infections in Central China. PLoS One 2015;10(3):e0119170.

5. Huang H-S, Tsai C-L, Chang I, Hsu T-C, Lin S, Lee C-C. Multiplex PCR system for the rapid diagnosis of respiratory virus infection: systematic review and meta-analysis. Clin Microbiol Infect 2018;24(10):1055-63.

6. Bayrakdar F, Altaş AB, Korukluoğlu G. Solunum yolu virüslerinin 2009-2012 yılları arasında ülkemizdeki mevsimsel dağılımı. Türk Mikrobiyol Cem Derg 2013;43:56-66.

7. Özışık L, Tanrıover MD, Akçay MÇ, Yuntcu K, Ünal S, Badur $S$ ve ark. Influenza benzeri hastalık nedeniyle hastaneye yatış gerektiren hastalarda mortaliteyle ilişkili faktörler. Mikrobiyol Bul 2017;51(1):20-31.

8. Harris AM, Hicks LA, Qaseem A. Appropriate antibiotic use for acute respiratory tract infection in adults: Advice for high-value care from the American College of Physicians and the Centers for Disease Control and Prevention. Ann Intern Med 2016;164(6):425-34.

9. Karalı E, Sebit T, Arslan N. Akut solunum yolu enfeksiyonu olan hastalarda hızlı influenza tanı testi ile influenza $A$ ve $B$ antijenlerinin araştırılması. Dicle Tıp Dergisi 2020;47(2):359-65.

10. Badur S. Influenza Epidemiyolojisi. Erişim Tarihi: 10 Ekim 2020. Erişim adresi: http://www.ankaramikrobiyoloji.org. tr/docs/50yil/selimbadur.pdf.

11. Suntur BM, Kaya H, Kuşcu F. Bir mevsimsel influenza epidemisi deneyimi. Ege Tıp Dergisi 2018;57(1):46-50.
12. Centers for Disease Control and Prevention: 2019-2020 U.S. Flu Season: Preliminary In-Season Burden Estimates. Accessed date: 15 October 2020. Available from: https:// www.cdc.gov/flu/about/burden/preliminary-in-season-estimates.htm.

13. Meşe S, Uyanık A, Asar S, Ağaçfidan A, Yenen OŞ. Influenza referans laboratuvarı 2015-2016 grip sürveyansı verileri. Türk Mikrobiyol Cem Derg 2016;46:172-80.

14. European Centre for Disease Prevention and Control: Summary of the influenza 2015-2016 Season in Europe. Accessed date: 01 October 2020. Available from: https://www. ecdc.europa.eu/en/publications-data/summary-influenza-2015-2016-season-europe.

15. Altaş AB, Bayrakdar F, Korukluoğlu G. 2015-2016 Sezonu influenza Sürveyansı Laboratuvar Sonuçlarının Değerlendirilmesi. XXXVII Türk Mikrobiyoloji Kongresi. 2016; Antalya, Türkiye. Erişim Tarihi: 12 Ekim 2020. Erişim adresi: https:// www.tmconline.org/Uploads/Editor/files/XXXVII_TMC_ Kongresi_Konusma_Ozetleri_ve_Bildiri_Kitabi_(2016).pdf Sayfa: 182

16. European Centre for Disease Prevention and Control. Influenza in Europe, Summary of the Season 2016-2017. Accessed date: 12 October 2020. Available from: https://www. ecdc.europa.eu/en/seasonal-influenza/season-2016-17

17. T.C. Sağlık Bakanlığı Halk Sağlığı Genel Müdürlüğü Bulaşıcı Hastalıklar Daire Başkanlığı. 2016-2017 Haftalık Influenza Raporları 2017. Erişim Tarihi: 12 Ekim 2020. Erişim adresi: https://grip.gov.tr/tr/2016-2017-haftalık-influenza-raporları.html.

18. European Centre for Disease Prevention and Control: Influenza in Europe, Summary of the season 2017-2018. Accessed date: 10 October 2020. Available from: https://www. ecdc.europa.eu/en/seasonal-influenza/season-2017-18.

19. T.C. Sağlık Bakanlığı Halk Sağlığı Genel Müdürlüğü Bulaşıcı Hastalıklar Daire Başkanlığı. 2017 - 2018 Haftalık Influenza Raporları 2018. Erişim Tarihi:15 Ekim 2020 Erişim adresi: https://grip.gov.tr/depo/influenza-raporu/2018/ Influenza Grip_Sürveyans_Raporu_2018_21-39_hafta_35fcc.pdf.

20. Akçay-Çiblak M, Aslan S, Bozkaya E, Badur S. Ülkemizde 2005-2006, 2006-2007 ve 2007-2008 yıllarında grip sürveyansı ve izole edilen infuenza virusu suşlarının tiplendirimi. Klimik 2008;21(3):87-92.

21. Altaş AB, Bayraktar F, Korukluoğlu G. Pandemi sonrası beş ardaşık sezonda influenza sürveyansı: Türkiye ulusal influenza merkezi bulguları. Mikrobiyol Bul 2016;50(3):401-17.

22. Nguyen HKL, Nguyen SV, Nguyen AP, Hoang PMV, Le TT, Nguyen TC, et al. Severe Acute Respiratory Infection (SARI) surveillance for hospitalized patients in Northern Vietnam, 2011-2014. Jpn J Infect Dis 2017;70(5):522-7.

23. Başaranoğlu ST, Bilgi E, Tanrı̈ver MD, Bosi TB. Influenza benzeri hastalık nedeniyle yatırılan hastalarda respiratuvar sinsityal virüs infeksiyonu sıklığı ve mortaliteye etkisi: prospektif, çok merkezli gerçek yaşam verileri. FLORA 2018;23(4):172-8. 
24. Horton KC, Dueger EL, Kandeel A, Abdallat M, El-Kholy A, Al-Awaidy S, et al. Viral etiology, seasonality and severity of hospitalized patients with severe acute respiratory infections in the Eastern Mediterranean Region, 2007-2014. PLoS One 2017;12(7):e0180954.

25. Russell CA, Jones TC, Barr IG, Cox NJ, Garten RJ, Gregory V, et al. Influenza vaccine strain selection and recent studies on the global migration of seasonal influenza viruses. Vaccine 2008;26(4):D31-34.

\section{Yazıșma Adresi/Address for Correspondence} Seda GÜDÜL HAVUZ

Samsun Bafra Nafiz Kurt Devlet Hastanesi, Tıbbi Mikrobiyoloji Kliniği,

Samsun-Türkiye

E-posta: drsedahavuz@hotmail.com 